\title{
Kommentar
}

\section{En sykehistorie med flere mulige forklaringer}

Dette er en komplisert sykehistorie. Varierende nevrologiske utfall over tid, aneurismedanning, multiple cerebrale infarkter og immunologisk betinget trombosetendens tolkes av forfatterne som best forklart av cervikal arteriedisseksjon og samtidig antifosfolipidsyndrom. Begge disse tilstandene er sjeldne.

Det er liten tvil om at pasienten har et antifosfolipidsyndrom. Han hadde både antistoffer mot fosfolipider i signifikant forhøyet konsentrasjon (antikardiolipinantistoff og anti- $\beta 2-G P 1$-antistoff) og lupusantikoagulant, som er en indirekte måte å påvise antistoffer som øker trombosetendensen på. I tillegg hadde han en klinisk hendelse: hjerneslag. Han får nå korrekt og sannsynligvis livslang antikoagulasjonsbehandling med warfarin.

Antifosfolipidsyndrom kan opptre alene som en isolert kronisk immunopati, men ses vanligvis som del av en annen immunologisk sykdom, for eksempel systemisk lupus erythematosus. Påvisning av forandringer på mitral- og aortaklaffen kan godt tenkes å representere Libman-Sacks' endokarditt, som fremfor alt forekommer ved systemisk lupus erythematosus. Det er meget sjelden at systemisk lupus erythematosus gir vaskulitt i så store kar - men det forekommer. Primær vaskulitt som affiserer halsarteriene og intracerebrale kar uten samtidig systemisk lupus erythematosus kan heller ikke utelukkes. Multiple og varierende nevrologiske utfall over tid bør alltid bringe tanken i retning av intracerebral vaskulitt.

Primær angiitt i sentralnervesystemet rammer utelukkende der. I tillegg kan alle andre nekrotiserende vaskulitter, slik som Wegeners granulomatose, polyarteritis nodosa og arteritis temporalis, gi intracerebral vaskulitt. Vaskulitter, som er kroniske inflammatoriske tilstander med varierende grad av immunaktivering, kan stundom føre til danning av antistoffer mot fosfolipider og et antifosfolipidsyndrom.

Denne komplekse problemstillingen viser nødvendigheten av at spesialister på forskjellige fagfelter samarbeider om utredningen av uklare og vanskelige sykdomstilstan- der. Den viktigste lærdommen av denne kasuistikken er betydningen av at man som lege er nysgjerrig og spørrende og våger å revurdere sine standpunkter og meninger når nye momenter dukker opp.

\section{Roald Omdal}

roald.omdal@lyse.net

Seksjon for klinisk immunologi

Medisinsk avdeling

Stavanger universitetssjukehus

Roald Omdal (f. 1950) er spesialist i indremedisin og revmatologi og professor $\mathrm{i}$ indremedisin ved Universitetet i Bergen. Han har spesielt arbeidet med nevrologiske manifestasjoner ved kroniske immunologiske sykdommer. Ingen oppgitte interessekonflikter.

Mottatt 9.2. 2011, første revisjon innsendt 10.3. 2011, godkjent 17.3. 2011. Medisinsk redaktør Petter Gjersvik. 